\title{
Changes in groundwater levels or pressures associated with the 2004 earthquake off the west coast of northern Sumatra (M9.0)
}

\author{
Yuichi Kitagawa, Naoji Koizumi, Makoto Takahashi, Norio Matsumoto, and Tsutomu Sato \\ Geological Survey of Japan, National Institute of Advanced Industrial Science and Technology, Japan
}

(Received July 25, 2005; Revised December 2, 2005; Accepted December 3, 2005; Online published February 17, 2006)

\begin{abstract}
Associated with the 2004 earthquake off the west coast of northern Sumatra, changes in groundwater levels or pressures were observed at many observation stations in Japan which are more than $5000 \mathrm{~km}$ from the hypocenter. At 38 of the 45 observation stations, there were changes in groundwater levels or pressures. At the 10 observation stations in which the Ishii-type borehole strain instruments were established, changes in crustal strains were also observed. A major part of the changes in crustal strains and groundwater levels or pressures were dynamic oscillations due to a seismic wave. At some stations, coseismic or postseismic rises or drops were also observed. At five stations where both crustal stain and groundwater levels or pressures were observed, postseismic changes in groundwater levels or pressures were consistent with coseismic static steps in crustal strains. At the other five stations, postseismic changes in groundwater levels or pressures did not agree with the coseismic static steps. At two stations of these five stations, it is anticipated that the pore water pressure change in each aquifer locally occurred independently of the change in crustal strain. At another station, postseismic changes in groundwater level possessed the same characteristics as a model removing the temporary deposition. At the last two stations, the causes of the changes are unknown.
\end{abstract}

Key words: Sumatra earthquake, groundwater level or pressure, crustal strain, oscillation due to a seismic wave, postseismic changes.

\section{Introduction}

It is known that groundwater level changes with a seismic wave of a distant earthquake (Rexin et al., 1962). It is thought that dynamic oscillation in crustal strain in an aquifer due to a seismic wave mainly causes dynamic oscillation in the groundwater level.

Cooper et al. (1965) and Kunugi et al. (2000) showed that the amplitude of the oscillation in groundwater level is enhanced in a particular period due to the characteristics of the well-aquifer system. Woodcock and Roeloffs (1996) compared groundwater level changes with broadband seismograms. On the other hand, Brodsky et al. (2003) investigated coseismic groundwater level steps and proposed a new model based on the removal of the temporary deposition barrier due to groundwater flow by seismic wave that causes a coseismic step. These papers mainly discussed groundwater level changes at one well related to seismic waves of several distant earthquakes.

Associated with the earthquake off the west coast of northern Sumatra (Mw 9.0) occurred at December 26, 2004, changes in groundwater levels or pressures were observed at many observation stations of Geological Survey of Japan, National Institute of Advanced Industrial Science and Technology (AIST), Research Center for Earthquake Prediction, Disaster Prevention Research Institute, Kyoto University, Tottori University, Hot Springs Research Institute of Kana-

Copyright (c) The Society of Geomagnetism and Earth, Planetary and Space Sciences (SGEPSS); The Seismological Society of Japan; The Volcanological Society of Japan; The Geodetic Society of Japan; The Japanese Society for Planetary Sciences; TERRAPUB gawa prefecture, Yamaguchi University, and Chugoku Electric Power Co. Inc. in Japan. These observation stations are more than $5000 \mathrm{~km}$ from the hypocenter. Consequently, it enables us to investigate the characteristics of groundwater level changes at many observation stations to a distant large earthquake. In addition, the Ishii-type borehole strain instruments were installed at some stations of AIST, and we compared the groundwater level changes with the crustal strain changes.

In this paper, we will report the characteristics of the groundwater level changes and crustal strain changes caused by the Sumatra earthquake. Based on the observed dynamic oscillations in crustal strains and groundwater levels or pressures due to the seismic wave, the strain sensitivities of the groundwater levels were estimated for several periods. We will also discuss the postseismic changes in groundwater levels or pressures compared with the coseismic strain steps.

\section{Observation}

AIST contracted the observation well network mainly in and around Tokai and Kinki districts for earthquake prediction (Fig. 1, Tsukuda, 2000; Tsukuda et al., 2000). To the avoid effects of rainfall and artificial pumping, depths of the wells are from $120 \mathrm{~m}$ to $1000 \mathrm{~m}$ and the screened depths of the wells are from $80 \mathrm{~m}$ to $800 \mathrm{~m}$. There is one well at each station which has single screen as shown in Table 1. However, there are two or more wells at some stations. As a result, there are 45 stations and 62 wells.

Groundwater levels in the open wells or pressures in the 
(a)
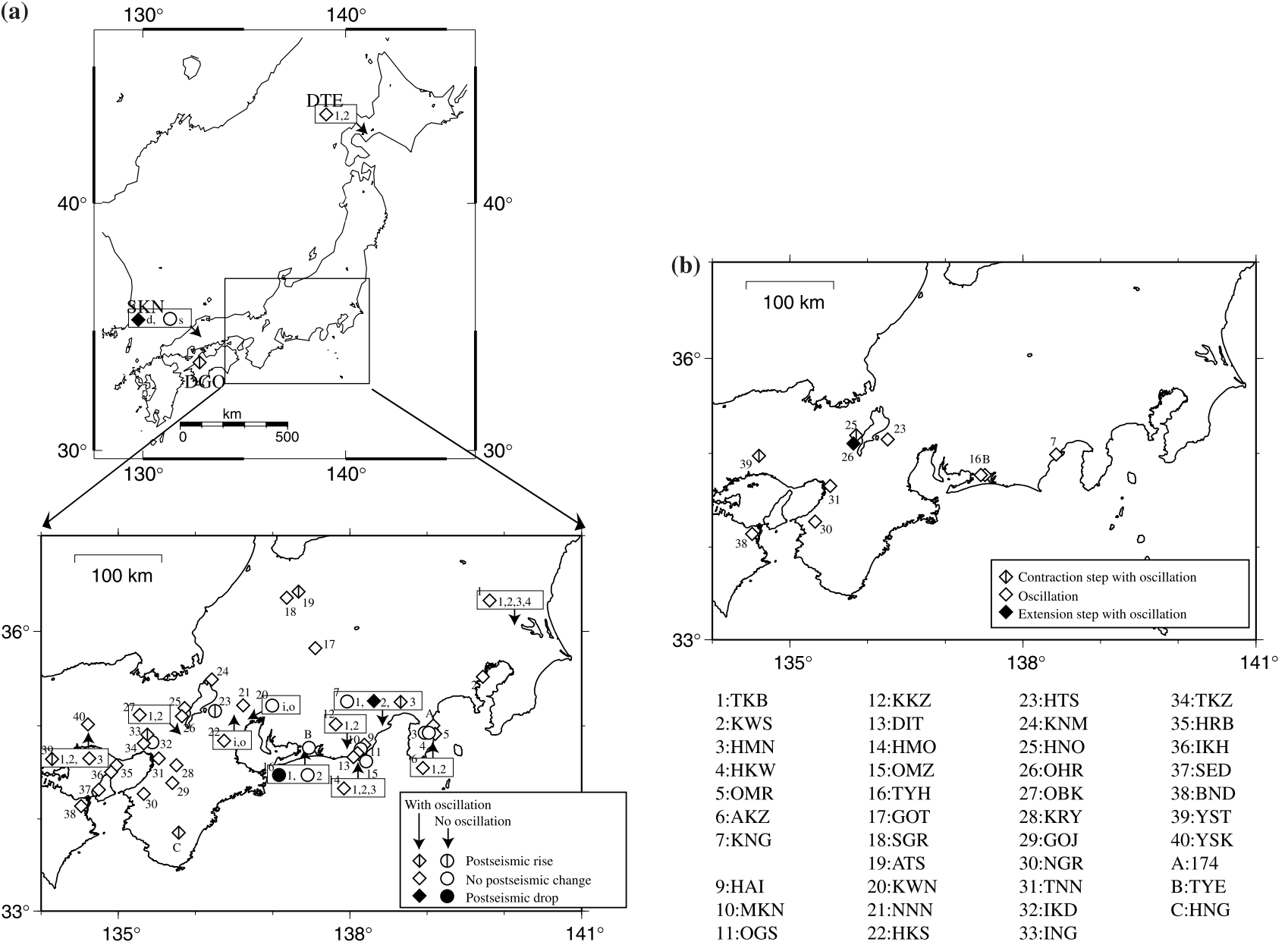

Fig. 1. Locations of observation stations. (a) Changes in groundwater levels or pressures. (b) Changes in crustal strains.

sealed wells are observed. Rainfall and barometric pressure are also observed. At some observation wells, crustal strain fields by the Ishii-type borehole strain instruments are observed (Table 1). The sampling interval of groundwater levels or pressures and crustal strain is mainly 2 minutes. Other sampling intervals are 1 second at HNO and YSK, 5 seconds at SKN, 0.05 seconds at YST, and 10 minutes at HNG and DGO. In addition, the sampling interval of crustal strain at $\mathrm{HNO}$ and OHR is 0.05 seconds.

\section{Results}

The changes in groundwater levels or pressures with the Sumatra earthquake were observed at 38 of the 45 observation stations and 52 of the 62 observation wells. A major part of the changes in groundwater levels or pressures were dynamic oscillations due to the seismic wave. At YSK, the maximum amplitude of the oscillation in groundwater pressure was $0.05 \mathrm{MPa}$, equivalent to the groundwater level of 5 meters (Fig. 2). Short-period oscillation of groundwater pressure was more clearly detected than that of groundwater level. In the case of an open well, the change in groundwater level needs a groundwater flow between an aquifer and well. Therefore, it is difficult for the groundwater level in an open well to reflect the short-period oscillation in the pore pressure of an aquifer. The effect is called the wellbore storage effect. Therefore, the wellbore storage effect affects changes in the groundwater level as a kind of high-cut filter (Hsieh et al., 1987; Hosoya and Tokunaga, 2003). As oscillation period is shorter, groundwater level change will become smaller. On the contrary, postseismic long-term changes in the groundwater levels or pressures were observed at 11 wells (Fig. 3). There were postseismic rises at eight wells and postseismic drops at three wells. The spatial distribution of postseismic changes did not have a clear tendency. Since borehole strain instruments were also installed at some stations, we will evaluate postseismic changes in groundwater levels or pressures against strain changes in a later section.

At the 10 stations where the Ishii-type borehole strain instruments were installed, dynamic oscillations in crustal strains were observed. The maximum amplitude of the oscillations in the crustal areal strains was on the order of $10^{-6}$ (Fig. 2). Coseismic static steps in crustal strains were observed at three of the ten stations (Fig. 4). Steps at two stations showed contractions, and a step at one station showed extension. At HNO, a large contractive step in areal strain $\left(-2.4 \times 10^{-7}\right)$ was observed.

It is usually thought that pore water pressure responds to crustal volumetric strain, not but to crustal areal strain. Since we observe three components of the horizontal crustal strain, crustal volumetric strain could not be estimated from the observation. However, it is expected that the crustal 
Table 1. List of 10 stations where the Ishii-type borehole strain instruments were installed.

\begin{tabular}{|c|c|c|c|c|c|c|c|c|}
\hline \multirow[b]{2}{*}{ Name } & \multirow{2}{*}{$\begin{array}{c}\text { Station } \\
\text { Well } \\
\text { Number }\end{array}$} & \multirow[b]{2}{*}{ Code } & \multirow[b]{2}{*}{ Latitude } & \multirow[b]{2}{*}{ Longtitude } & \multirow[b]{2}{*}{ Altitude } & \multirow{2}{*}{\multicolumn{2}{|c|}{$\begin{array}{c}\text { Strain } \\
\text { meter } \\
\text { depth } \\
\text { m }\end{array}$}} & \multirow[b]{2}{*}{ Geology } \\
\hline & & & & & & & & \\
\hline $\mathrm{BND}$ & & BND & $34.141 \mathrm{~N}$ & $134.517 \mathrm{E}$ & 25 & $419-430$ & 498 & Qs \\
\hline $\mathrm{HNO}$ & & HNO & $35.186 \mathrm{~N}$ & $135.857 \mathrm{E}$ & 476 & $235-246$ & 272 & PTs \\
\hline HTS & & HTS & $35.151 \mathrm{~N}$ & $136.256 \mathrm{E}$ & 125 & $338-360$ & 437 & Qs \\
\hline \multirow[t]{3}{*}{$\mathrm{KNG}$} & WELL1 & KNG1 & $34.988 \mathrm{~N}$ & $138.434 \mathrm{E}$ & 21 & $9-20$ & & Qs \\
\hline & WELL2 & KNG2 & $34.987 \mathrm{~N}$ & $138.433 \mathrm{E}$ & 21 & $224-235$ & & Qs \\
\hline & WELL3 & KNG3 & $34.988 \mathrm{~N}$ & $138.435 \mathrm{E}$ & 21 & $309-320$ & 336 & Ts \\
\hline NGR & & NGR & $34.279 \mathrm{~N}$ & $135.331 \mathrm{E}$ & 90 & $402-446$ & 616 & Qs \\
\hline OHR & & OHR & $35.107 \mathrm{~N}$ & $135.822 \mathrm{E}$ & 217 & $256-267$ & 280 & PTV \\
\hline $\mathrm{TNN}$ & & $\mathrm{TNN}$ & $34.656 \mathrm{~N}$ & $135.515 \mathrm{E}$ & 10 & $447-464$ & 543 & Qs \\
\hline TYE & & TYE & $34.766 \mathrm{~N}$ & $137.470 \mathrm{E}$ & 93 & 186-208 & 269 & PTs \\
\hline \multirow[t]{2}{*}{ TYH } & WELL1 & TYH1 & $34.764 \mathrm{~N}$ & $137.467 \mathrm{E}$ & 76 & $182-198$ & 250 & \\
\hline & WELL2 & TYH2 & $34.764 \mathrm{~N}$ & $137.467 \mathrm{E}$ & 76 & $135-150$ & & PTs \\
\hline \multirow[t]{3}{*}{ YST } & WELL1 & YST1 & $34.982 \mathrm{~N}$ & $134.611 \mathrm{E}$ & 126 & $254-265$ & 288 & PTs \\
\hline & WELL2 & YST2 & $34.982 \mathrm{~N}$ & 134.611E & 126 & $144-150$ & & PTs \\
\hline & WELL3 & YST3 & $34.982 \mathrm{~N}$ & $134.611 \mathrm{E}$ & 126 & $144-150$ & & PTs \\
\hline
\end{tabular}

Qs: Quaternary sedimentary rocks

Ts: Tertiary sedimentary rocks

PTs: Pre-Tertiary sedimentary rocks

PTv: Pre-Tertiary volcanic rocks

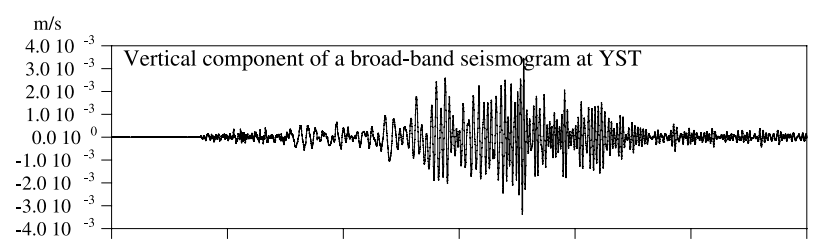

areal strain is proportional to crustal volumetric strain at depths of the observation wells where the free surface condition is applicable. The crustal areal strain is 1.5 times as large as crustal volumetric strain assuming the Poisson ratio of the crust is 0.25 (Melchior, 1983). Consequently, we compared changes in the groundwater levels or pressures with changes in the crustal areal strains.
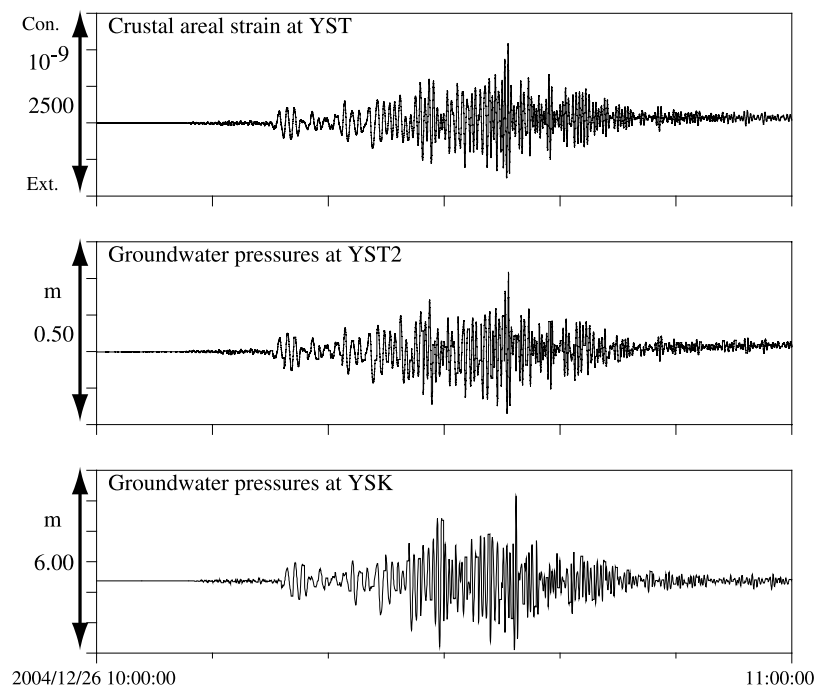

Fig. 2. Observed dynamic oscillations of the vertical component of a broad-band seismogram at YST, crustal areal strain at YST, and groundwater pressures at YST2 and YSK when the seismic wave of the Sumatra earthquake passed through.

\subsection{Characteristics of dynamic oscillations in the groundwater levels or pressures}

It is known that the Rayleigh wave phases of the Sumatra earthquake, which traveled around the earth more than five times, are clearly observed using a broad-band seismograph array (Yoshizawa, 2005). We found the groundwater pressure at YSK responded to seismic wave phases that traveled up to four times around the earth (Fig. 5). Comparing the groundwater pressure with the crustal strain at $\mathrm{HNO}$, the oscillation components in the groundwater pressure were very similar to those in crustal areal strain (Fig. 6). Therefore, we believe that the oscillation in the groundwater pressure was caused by a dynamic oscillation in strain of the aquifer due to the seismic wave. Using these oscillation records, the strain sensitivity of the groundwater pressure is calculated in periods between a few tens of seconds and a few hundreds of seconds. As a result, strain sensitivity was estimated to be $0.30-0.35 \mathrm{~mm}$ per $10^{-9}$ areal strain in a period of a few tens of seconds and $0.45-0.50 \mathrm{~mm}$ per $10^{-9}$ areal strain in a period of a few hundreds of seconds. These values are much smaller than the strain sensitivities for M2 (period of 12.4 hours) and $\mathrm{O} 1$ (period of 25.8 hours) com- 

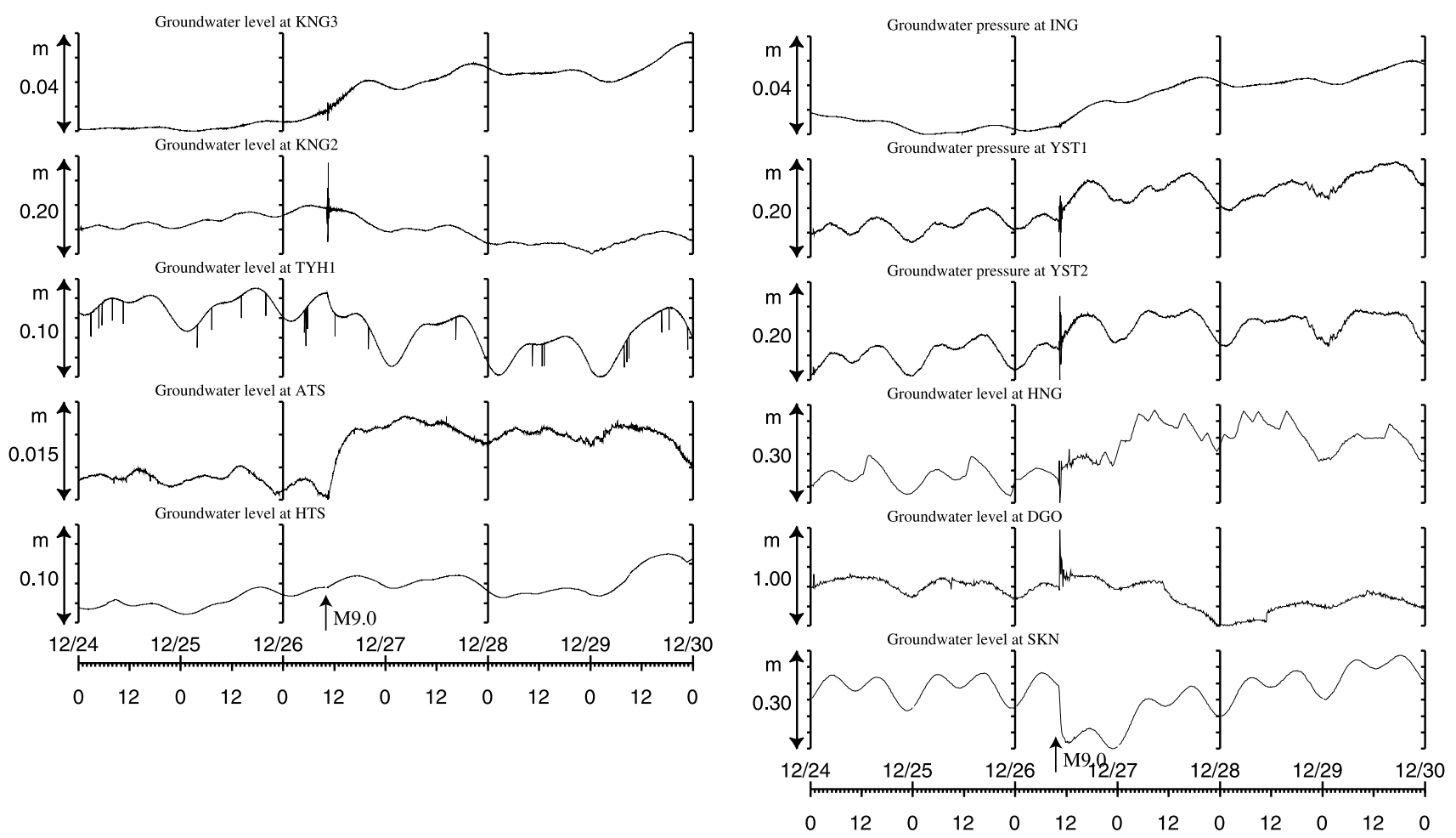

Fig. 3. Some examples of observed postseismic changes in groundwater levels or pressures with the Sumatra earthquake.
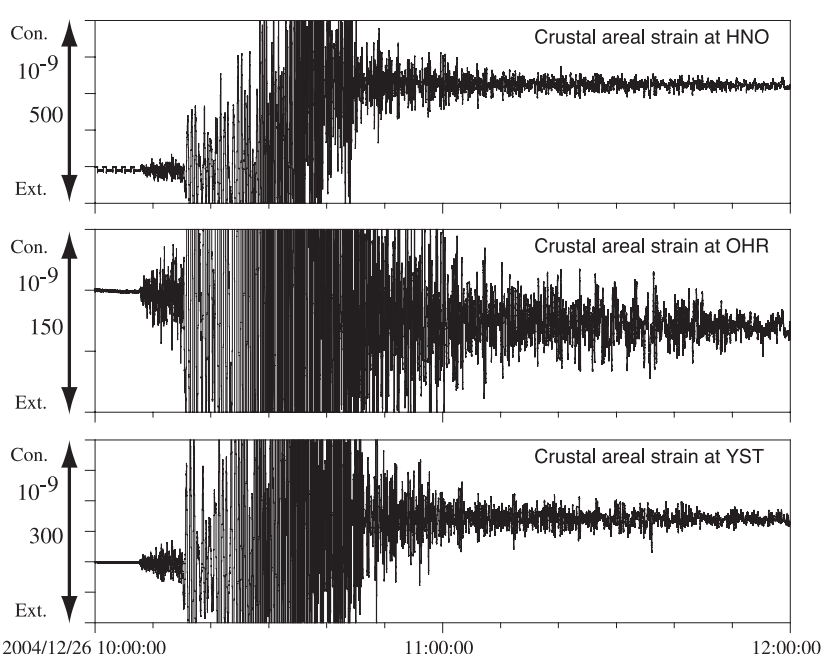

2004/12/26 10:00:00

11:00:00

12:00:00

Fig. 4. Observed oscillation and steps in crustal strains due to the Sumatra earthquake.

ponents of the tidal phenomena (Table 2). The shorter the period is, the smaller the strain sensitivity of groundwater pressure tends to be.

\subsection{Characteristics of coseismic strain steps and post-} seismic changes in groundwater levels or pressures

At 10 stations where the borehole strainmeters are set, we checked for the occurrence of coseismic strain steps and postseismic changes in the groundwater levels or pressures. The postseismic changes in the groundwater levels or pressures were compared with coseismic strain steps using the strain sensitivities of groundwater levels or pressures estimated from the tidal phenomena (Table 2). The results are

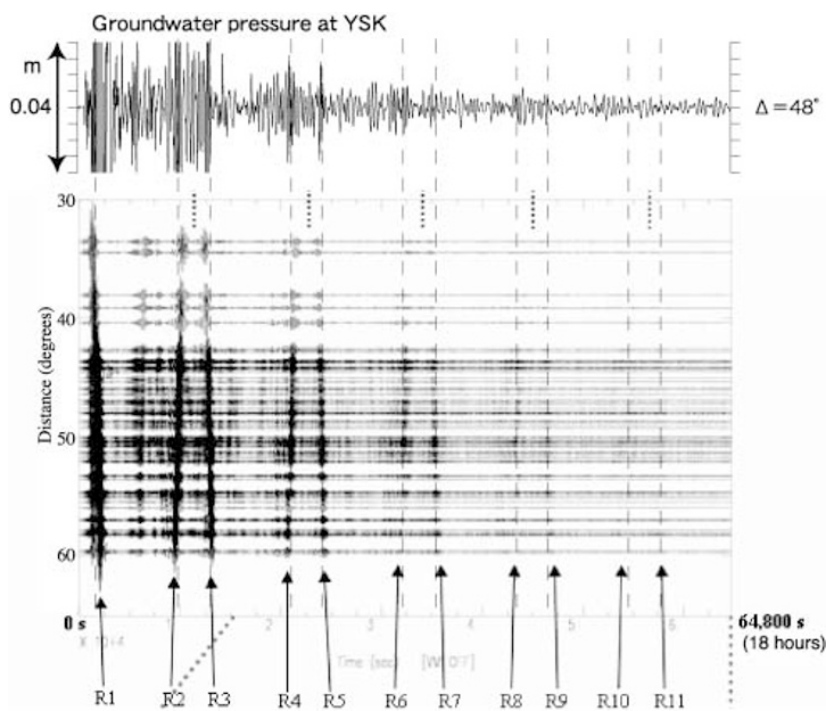

Fig. 5. Dynamic oscillation in groundwater pressure at YSK with the surface wave of the Sumatra earthquake. Upper graph shows groundwater pressure through a band-pass filter with a 200-500 second range. Lower graph was quoted from the Web site of Dr. Yoshizawa (http://noreply.ep.sci.hokudai.ac.jp/s̃eis/sumatra/). R1 means a Rayleigh wave phase, which directly travels from the hypocenter to the stations through the near side of the earth's surface. R2 means a Rayleigh wave phase, which travels through the far side of the earth's surface. R3, R5, R7, R9 and R11 is a phase, which travels from the hypocenter to stations through the near side of the earth's surface and circle around the earth 1, 2, 3, 4 and 5 times, respectively. R4, R6, R8 and R10 is a phase which travels from the hypocenter to the stations through the far side of the earth and circle around the earth 1, 2, 3 and 4 times, respectively. 
Table 2. The strain sensitivities based on tidal responses of groundwater levels using GOTIC2 (Matsumoto et al., 2001) and BAYTAP-G (Ishiguro et al., 1983; Tamura et al., 1991).

\begin{tabular}{|c|c|c|c|c|c|c|}
\hline Code & $\begin{array}{l}\text { Tidal } \\
\text { Comp }\end{array}$ & $\begin{array}{c}\text { Phase Shift } \\
\text { degree } \\
-: \text { Lag }\end{array}$ & Error & $\begin{array}{c}\text { Amplitude } \\
\mathrm{mm} / 10^{-8}\end{array}$ & Error & Amp ave \\
\hline \multirow[t]{2}{*}{ BND } & $\mathrm{O} 1$ & -20.3 & 5.9 & 14.53 & 1.51 & 12.97 \\
\hline & M2 & -15.0 & 1.0 & 11.41 & 0.20 & \\
\hline \multirow[t]{2}{*}{ HNO } & $\mathrm{O} 1$ & -2.6 & 1.7 & 15.41 & 0.44 & 14.86 \\
\hline & M2 & -0.9 & 0.3 & 14.31 & 0.07 & \\
\hline \multirow[t]{2}{*}{ HTS } & $\mathrm{O} 1$ & -55.4 & 6.5 & 1.87 & 0.21 & 1.38 \\
\hline & M2 & -76.0 & 2.0 & 0.88 & 0.03 & \\
\hline \multirow[t]{2}{*}{ KNG1 } & $\mathrm{O} 1$ & -285.9 & 77.3 & 0.41 & 0.56 & 0.35 \\
\hline & M2 & -273.6 & 23.2 & 0.28 & 0.11 & \\
\hline \multirow[t]{2}{*}{ KNG2 } & $\mathrm{O} 1$ & -0.7 & 2.2 & 3.65 & 0.14 & 3.98 \\
\hline & M2 & 6.8 & 0.4 & 4.30 & 0.03 & \\
\hline \multirow[t]{2}{*}{ KNG3 } & $\mathrm{O} 1$ & -50.1 & 20.0 & 0.73 & 0.26 & 0.52 \\
\hline & M2 & -69.3 & 9.6 & 0.31 & 0.05 & \\
\hline \multirow[t]{2}{*}{ NGR } & $\mathrm{O} 1$ & -64.6 & 9.3 & 0.07 & 0.01 & 0.06 \\
\hline & M2 & -68.8 & 6.3 & 0.05 & 0.01 & \\
\hline \multirow[t]{2}{*}{ OHR } & $\mathrm{O} 1$ & 5.2 & 2.4 & 13.64 & 0.56 & 13.90 \\
\hline & M2 & -0.2 & 0.3 & 14.15 & 0.08 & \\
\hline \multirow[t]{2}{*}{$\mathrm{TNN}$} & $\mathrm{O} 1$ & -12.2 & 0.6 & 5.22 & 0.06 & 4.84 \\
\hline & M2 & -30.4 & 0.1 & 4.45 & 0.01 & \\
\hline \multirow[t]{2}{*}{ TYE } & $\mathrm{O} 1$ & -71.7 & 0.9 & 5.07 & 0.08 & 3.92 \\
\hline & M2 & -78.2 & 0.4 & 2.76 & 0.02 & \\
\hline \multirow[t]{2}{*}{ TYH1 } & $\mathrm{O} 1$ & -47.5 & 1.4 & 11.47 & 0.29 & 9.32 \\
\hline & M2 & -66.1 & 0.6 & 7.16 & 0.07 & \\
\hline \multirow[t]{2}{*}{ TYH2 } & $\mathrm{O} 1$ & 5.3 & 1.2 & 12.96 & 0.28 & 13.10 \\
\hline & M2 & -12.0 & 0.4 & 13.23 & 0.08 & \\
\hline \multirow[t]{2}{*}{ YST1 } & $\mathrm{O} 1$ & -21.4 & 2.4 & 8.30 & 0.03 & 8.84 \\
\hline & M2 & -25.5 & 0.9 & 9.37 & 0.01 & \\
\hline \multirow[t]{2}{*}{ YST2 } & $\mathrm{O} 1$ & -9.0 & 3.2 & 12.73 & 0.71 & 14.22 \\
\hline & M2 & -13.9 & 0.4 & 15.71 & 0.12 & \\
\hline \multirow[t]{2}{*}{ YST3 } & $\mathrm{O} 1$ & -40.7 & 2.4 & 4.87 & 0.20 & 4.53 \\
\hline & M2 & -34.4 & 0.4 & 4.19 & 0.03 & \\
\hline
\end{tabular}

summarized in Table 3. At YST, the amplitudes and signs of postseismic changes in groundwater pressures agreed with the amplitude and sign of the coseismic strain step. At TYE, TNN, BND and NGR, both the crustal strains and groundwater levels or pressures do not change and seems consistent. Despite there was no coseismic strain step at KNG2, TYH1, and HTS, long-term groundwater level changes occurred after the Sumatra earthquake. Although cosesimic strain steps were observed at HNO and OHR, there were no long-term changes in the groundwater level or pressure. We presumed that these observed strain steps were too large to be explained by large-scale static crustal strain changes due to seismogenic faulting of the Sumatra earthquake.

\section{Discussions}

When postseismic changes in groundwater levels or pressures did not agree with the coseismic strain steps, the following two mechanisms should be checked. Roeloffs (1998) and Matsumoto and Roeloffs (2003) concluded that repeated postseismic changes in groundwater level were quantitatively explained by the diffusion of abrupt coseismic pore water pressure changes near the well. Brodsky et al. (2003) proposed a new model based on the removal of the temporary deposition barrier in a fracture due to groundwater flow by seismic wave that causes a coseismic steplike groundwater level changes due to distant earthquakes. Based on the barrier removal model, coseismic step-like groundwater level changes will not occur again until the recreation of the barrier. The model suggests that coseismic groundwater level change should occur just one time for a series of seismic activity.

At KNG2, TYH1, and HTS, several previous postseismic changes in groundwater levels were mainly the same as the postseismic changes associated with the Sumatra earthquake (Tsukuda, 2000; Koizumi et al., 2002; Takahashi et al., 2002; Sato et al., 2005). In the case of the M7.1 and M7.4 off Kii peninsula earthquakes that occurred within 5 hours on September 5, 2004, postseismic groundwater level 
Table 3. List of coseismic steps in crustal strains and postseismic changes in groundwater levels or pressures with the Sumatra earthquake at 10 stations in Table 1. The values of converted volumetric strain are estimated from the postseismic changes in groundwater levels or pressures using the strain sensitivities in Table 2 .

\begin{tabular}{|c|c|c|c|c|c|c|c|}
\hline \multirow[b]{2}{*}{ Code } & \multicolumn{2}{|c|}{$\begin{array}{l}\text { Observed } \\
\text { areal strain } \\
\text { step }\end{array}$} & \multicolumn{3}{|c|}{$\begin{array}{c}\text { Groundwater level } \\
\text { change }\end{array}$} & \multicolumn{2}{|c|}{$\begin{array}{l}\text { Converted areal } \\
\text { strain changes } \\
\text { from GL change }\end{array}$} \\
\hline & $\begin{array}{l}\text { Sign } \\
+: \text { Ext }\end{array}$ & $\begin{array}{l}\text { Amp } \\
10^{-9}\end{array}$ & $\begin{array}{l}\text { Sign } \\
+: \text { UP }\end{array}$ & $\begin{array}{l}\text { Amp } \\
\mathrm{cm}\end{array}$ & $\begin{array}{c}\text { Duration } \\
\text { day }\end{array}$ & $\begin{array}{l}\text { Sign } \\
+: \text { Ext }\end{array}$ & $\begin{array}{l}\text { Amp } \\
10^{-9}\end{array}$ \\
\hline BND & & $<5$ & & $<2$ & & & $<23$ \\
\hline HNO & - & 240 & & $<1$ & & & $<10$ \\
\hline HTS & & $<30$ & + & 1 & $<1$ & - & 109 \\
\hline KNG1 & & & & 0 & & & 0 \\
\hline KNG2 & & & - & 8 & $4-5$ & + & 302 \\
\hline KNG3 & & $<10$ & + & 2 & $2-3$ & - & 577 \\
\hline NGR & & $<5$ & & 0 & & & 0 \\
\hline OHR & + & 16 & & $<1$ & & & $<11$ \\
\hline TNN & & $<5$ & & 0 & & & 0 \\
\hline TYE & & $<5$ & & 0 & & & 0 \\
\hline TYH1 & & $<10$ & - & 3 & $<1$ & + & 48 \\
\hline TYH2 & & & & $<1$ & & & $<11$ \\
\hline YST1 & - & 70 & + & 6 & $<1$ & - & 102 \\
\hline YST2 & & & + & 7 & $<1$ & - & 74 \\
\hline YST3 & & & & $<2$ & & & $<66$ \\
\hline
\end{tabular}
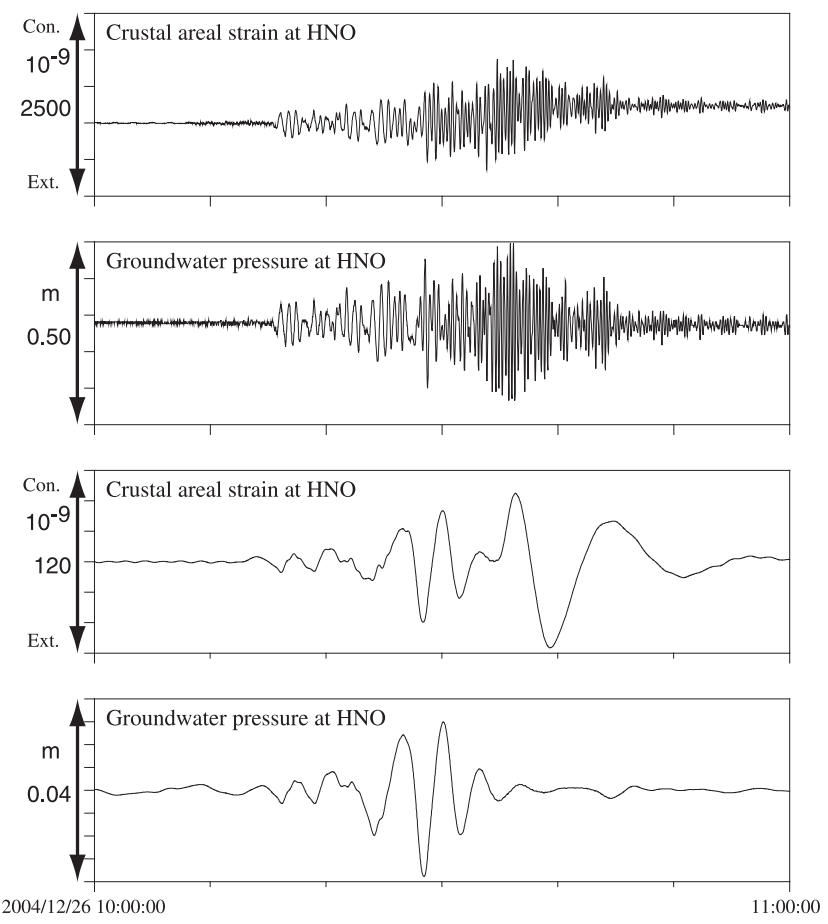

Fig. 6. Dynamic oscillations in crustal strain and groundwater pressure with the Sumatra earthquake. Uppermost and middle-upper graphs show the raw data. Lower-middle and lowermost graphs show the results through a band-pass filter with a 200-500 second range. drops at KNG2 and TYH1 occurred for both events. On the other hand, at HTS, the groundwater level started to rise after the M7.1 foreshock, but the groundwater level did not change after the M7.4 main shock. At KNG2 and TYH1, postseismic changes in groundwater levels possess the same characteristics as in the cases of Roeloffs (1998) and Matsumoto and Roeloffs (2003). Therefore, it is expected that the mechanism of postseismic changes at KNG2 and TYH1 is similar to that of Roeloffs (1998) and Matsumoto and Roeloffs (2003). At HTS, postseismic changes in groundwater levels possess more similar characteristics as the barrier removal model by Brodsky et al. (2003) than the model by Roeloffs (1998) and Matsumoto and Roeloffs (2003).

At HNO and OHR, despite large coseismic static steps in crustal strains, the groundwater levels did not change after the Sumatra earthquake. The possible reason is that groundwater level reflects the average pore pressure change in the aquifer, although the borehole strain sensors mainly detect this change in the vicinity of each well. We have no specific information on the heterogeneity in geology near these stations. However it is hypothesized that crustal strain changes very locally due to the heterogeneity in geological structure in the vicinity of the well while the average pore water pressure in an aquifer cannot change.

\section{Conclusions}

Changes in groundwater levels or pressures with the Sumatra earthquake were observed at 38 of 45 stations and 52 of 62 wells. Changes in crustal strains were observed at 10 observation stations. It is shown that dynamic oscilla- 
tions in groundwater levels or pressures respond to dynamic oscillations in crustal areal strains due to a seismic wave. Based on observed oscillations in groundwater pressure and crustal strain at HNO, the strain sensitivity of groundwater pressure is estimated. The shorter the period is, the smaller the strain sensitivity of groundwater pressure is. We compared postseismic changes in groundwater levels or pressures with coseismic strain steps at the 10 stations. Postseismic changes in groundwater levels or pressure and coseismic static steps in crustal strains were consistent at five stations and were not consistent at the other five stations. At two of these five stations, it is presumed that the cause of postseismic changes in groundwater levels is a diffusion of abrupt coseismic pore water pressure changes near a well. At another station, it is presumed that the mechanism of postseismic changes in groundwater level is same as the barrier removal model. However this interpreting is poorly supported by observation results and theories at the present time.

Acknowledgments. We had cooperation from the Shizuoka Prefectural Government, Tanabe city in Wakayama Prefecture, Matsuyama city in Ehime Prefecture, Yamaguchi University, and Chugoku Electric Power Co. Inc. on the establishment and management of the observation stations. A part of the used data was recorded by Hi-net of the National Research Institute for Earth Science and Disaster Prevention. We are grateful to those mentioned above. We also thank Dr. Ryuji Ikeda and an anonymous reviewer for their helpful comments.

\section{References}

Brodsky, E. E., E. A. Roeloffs, D. Woodcock, and I. Gall, A mechanism for sustained groundwater pressure changes induced by distance earthquakes, J. Geophys. Res., 108, 2390, doi:1029/2002JB002321, 2003.

Cooper, H. H., Jr., J. D. Bredehoeft, I. S. Papadopulos, and R. R. Bennett, The response of well-aquifer systems to seismic waves, J. Geophys. Res., 70, 3915-3926, 1965.

Hosoya, S. and T. Tokunaga, Determination of hydraulic properties from the responses of pore pressure and water level in wells to atmospheric loading and earth tides, Jour. Groundwater Hydrology, 45, 299-318, 2003 (in Japanese).

Hsieh, P. A., J. D. Bredehoeft, and J. M. Farr, Determination of Aquifer Transmissivity from earth tide analysis, Water Resour. Res., 23, 18241832, 1987.

Ishiguro, M., H. Akaike, M. Ooe, and S. Nakai, A Bayesian approach to the analysis of earth tides, Proc. 9th International Symposium on Earth
Tides, 283-292, 1983.

Koizumi, N., Y. Kitagawa, M. Takahashi, T. Sato, N. Matsumoto, H. Ito, Y. Kuwahara, A. Cho, and T. Sato, Changes in groundwater level and crustal strain in and around the Kinki district related to the 2001 Geiyo earthquake, Zishin, 55, 119-127, 2002 (in Japanese).

Kunugi, T., Y. Fukao, and M. Ohno, Underdamped responses of a well to nearby swarm earthquakes off the coast of Ito City, central Japan, 1995, J. Geophys. Res., 105, 7805-7818, 2000.

Matsumoto, K., T. Sato, T. Takanezawa, and M. Ooe, GOTIC2: A Program for Computation of Oceanic Tidal Loading Effect, J. Geod. Soc. Japan, 47, 243-248, 2001.

Matsumoto, N. and E. A. Roeloffs, Hydrological response to earthquakes in the Haibara well, central Japan-II. Possible mechanism inferred from time-varying hydraulic properties, Geophys. J. Int., 155, 899-913, 2003.

Melchior, P., The Tides of the Planet Earth, 2nd ed., 641 pp., Pergamon, New York, 1983.

Rexin, E. E., J. Oliver, and D. Prentiss, Seismically induced fluctuations of the water level in the Nunn-Bush well in Milwaukee, Bull. Seismol. Soc. Am., 52, 17-25, 1962.

Roeloffs, E. A., Persistent water level changes in a well near Parkfield, California, due to local and distant earthquakes, J. Geophys. Res., 103, 869-889, 1998.

Sato, T., N. Matsumoto, Y. Kitagawa, N. Koizumi, M. Takahashi, Y. Kuwahara, A. Cho, T. Satoh, and K. Ozawa, Report of changes in groundwater level associated with the 2004 off Kii-peninsula earthquakes, Chishitsu News, 611, 10-20, 2005 (in Japanese).

Takahashi, M., N. Koizumi, T. Sato, N. Matsumoto, H. Ito, Y. Kuwahara, A. Cho, and T. Sato, Changes in groundwater level and crustal strain in and around the Kinki district related to the Western Tottori earthquake in 2000, Zisin, 55, 75-82, 2002 (in Japanese).

Tamura, Y., T. Sato, M. Ooe, and M. Ishiguro, A procedure for tidal analysis with a Bayesian information criterion, Geophys. J. Int., 104, 507-516, 1991.

Tsukuda, E., Groundwater monitoring studies in the Tokai intensified observation area and other special observation areas for earthquake prediction research, Bull. Geol. Surv. Japan, 51, 391-400, 2000 (in Japanese).

Tsukuda, E., N. Koizumi, and Y. Kuwahara, Integrated groundwater monitoring studies in the intensified observation area and near major active faults, Bull. Geol. Surv. Japan, 51, 435-445, 2000 (in Japanese).

Woodcock, D. and E. A. Roeloffs, Seismically induced water-level oscillation in a fractured-rock aquifer well near Grants Pass, Oregon, Oregon Geology, 58, 27-33, 1996.

Yoshizawa, K., Multiple orbit surface waves excited by the great Sumatra earthquake and directivity effects of the infinite moving source, abstracts of 2005 Japan earth and planetary science joint meeting, J113P014, 2005.

Y. Kitagawa (e-mail: y-kitagawa@aist.go.jp), N. Koizumi, M. Takahashi, N. Matsumoto, and T. Sato 